Beata Starek-Świechowicz

\title{
THE EFFECTS OF 2-METHOXYETHANOL AND 2-ETHOXYETHANOL ON HEMATOLOGICAL CHANGES INDUCED BY 2-BUTOXYETHANOL
}

\author{
WPŁYW 2-METOKSYETANOLU I 2-ETOKSYETANOLU NA ZMIANY HEMATOLOGICZNE \\ INDUKOWANE PRZEZ 2-BUTOKSYETANOL
}

\author{
${ }^{1}$ Jagiellonian University / Uniwersytet Jagielloński, Kraków, Poland \\ Medical College, Faculty of Pharmacy, Department of Biochemical Toxicology / Collegium Medicum, Wydział Farmaceutyczny, \\ Zakład Biochemii Toksykologicznej \\ ${ }^{2}$ Central Institute for Labour Protection - National Research Institute / Centralny Instytut Ochrony Pracy - Państwowy Instytut \\ Badawczy, Warszawa, Poland \\ Department of Chemical, Aerosol and Biological Hazards, Laboratory of Toxicology / Zakład Zagrożeń Chemicznych, \\ Aerozolowych i Biologicznych, Laboratorium Toksykologiczne \\ ${ }^{3}$ Polish Academy of Sciences / Polska Akademia Nauk, Kraków, Poland \\ Institute of Pharmacology, Department of Experimental Neuroendocrinology / Instytut Farmakologii, \\ Zakład Neuroendokrynologii Doświadczalnej
}

\begin{abstract}
Background: Alkoxyethanols (ethylene glycol alkyl ethers) are used as mixtures in a variety of industrial and household products. The aim of this study has been to evaluate the effects of 2-methoxyethanol (ME) and 2-ethoxyethanol (EE) on hematological changes induced by 2-butoxyethanol (BE) in rats. Material and Methods: Experiments were performed on male Wistar rats treated subcutaneously with BE, ME, and EE alone (in the dose of $0.75 \mathrm{mM} / \mathrm{kg} / \mathrm{day}$ and $1.25 \mathrm{mM} / \mathrm{kg} /$ day) and their mixtures with the molar ratio 1:1, for 4 weeks. Hematological analyses were performed on the day $0,4,11,18$, and 29. Hemoglobin (HGB) concentration in the urine was also determined in the rats treated with $\mathrm{BE}$ alone and co-exposed to $\mathrm{BE}$ and $\mathrm{ME}$ and also $\mathrm{BE}$ and $\mathrm{EE}$. Results: The rats co-exposed to $\mathrm{BE}$ and $\mathrm{ME}$ or BE and $\mathrm{EE}$ demonstrated significantly less pronounced hematological changes in comparison with animals treated with $\mathrm{BE}$ alone at the beginning of exposure. At the later period the hematological alterations in the same animals were markedly pronounced and progressing with exposure time. The rats co-exposed to BE and ME or BE and EE did not demonstrate hemoglobinuria. Conclusions: ME or EE co-administered to rats with BE lead to the amelioration in the majority of the hematological parameters at the beginning of the exposure. The hematological changes at the end of the co-exposure to $\mathrm{BE}$ and $\mathrm{ME}$ or $\mathrm{BE}$ and $\mathrm{EE}$ were markedly pronounced. The effects observed in this study appear to be related with metabolic interactions of the examined ether. Med Pr 2015;66(3):303-315
\end{abstract}

Key words: rats, 2-butoksyethanol, 2-methoxyethanol, 2-ethoxyethanol, interactions, combined exposure

\section{STRESZCZENiE}

Wstęp: Alkoksyetanole (etery alkilowe glikolu etylowego) są stosowane jako mieszaniny w różnych produktach przemysłowych i domowych. Celem badania była ocena wpływu 2-metoksyetanolu (ME) i 2-etoksyetanolu (EE) na zmiany hematologiczne indukowane przez 2-butoksyetanol (BE) u szczurów. Materiał i metody: Samce szczurów rasy Wistar narażano drogą podskórną na BE, ME lub EE (w dawce $0,75 \mathrm{mM} / \mathrm{kg} /$ dzień i $1,25 \mathrm{mM} / \mathrm{kg} /$ dzień) oraz na ich mieszaniny w stosunku molowym (1:1) przez 4 tygodnie. Badania hematologiczne krwi obwodowej przeprowadzono w 0., 4., 11., 18. i 29. dniu doświadczenia. Ponadto na początku narażenia oznaczono stężenie hemoglobiny w moczu szczurów otrzymujących tylko BE oraz tylko jego mieszaninę z ME lub EE. Wyniki: Szczury narażone łącznie na badane związki wykazywały na początku ekspozycji słabiej zaznaczone zmiany hematologiczne niż zwierzęta otrzymujące tylko BE. W późniejszym okresie zmiany te były wyraźne i narastały wraz z czasem trwania narażenia. U szczurów eksponowanych na mieszaniny alkoksyetanoli nie zaobserwowano hemoglobinurii charakterystycznej dla działania samego BE. Wnioski: Poprawa parametrów hematologicznych na początku narażenia może być spowodowana hamującym działaniem ME i EE na metabolizm BE. Z kolei akumulacja kwasów metoksyoctowego i etoksyoctowego, czyli metabolitów odpowiednio ME i EE, może być przyczyną wyraźnych zmian hematologicznych na końcu ekspozycji. Med. Pr. 2015;66(3):303-315

Słowa kluczowe: szczury, 2-butoksyetanol, 2-metoksyetanol, 2-etoksyetanol, interakcje, narażenie łączne

Corresponding author / Autorka do korespondencji: Beata Starek-Świechowicz, Jagiellonian University, Medical College,

Faculty of Pharmacy, Department of Biochemical Toxicology, Medyczna 9, 30-688 Kraków, Poland,

e-mail: beata.starek@gmail.com

Received: October 14, 2014, accepted: January 20, 2015 


\section{INTRODUCTION}

A number of natural and synthetic chemicals are now clearly recognized to be both hemopoietic and hemolytic xenobiotics. For example, benzene is a classical hemopoietic xenobiotic, for which toxic and leukemogenic effects in humans and animal species are well-documented in the literature $[1,2]$. Lead causes inhibition of hemoglobin (HGB) biosynthesis and is a causal factor of hemolytic anemia induced by a decrease in $\mathrm{Na}^{+}$, $\mathrm{K}^{+}$-ATPase activity in erythrocytic membrane [3]. Exposure to ethylene glycol ether (EGEs) and related acetates may lead to peripheral hematological disorders and bone marrow injuries [4], sometimes complicated by aplastic anemia or immunodeficiency. Ethylene glycol ether was found to be potent hemopoietic xenobiotics in vitro, which acts directly on the hemopoietic cells [5].

Ethylene glycol ether, especially 2-methoxyethanol (ME) (CAS No. 109-86-4), 2-ethoxyethanol (EE) (CAS No. 110-80-5), and 2-butoxyethanol (BE) (CAS No. 111-76-2), has the unique solvent characteristics, i.e., solubility in water and organic compounds such as oils. The amphiphilic structure, the hydrophilic part binds to water, whereas lypophilic part binds to oils. The ether is applied to dissolve, extract, suspend, dry, and synthesize. Ethylene glycol ether is widely used in industry as an ingredient of paints, inks, waterbased cleaners, adhesives, detergents, cosmetics, cutting fluids, agrochemicals, jet fuels, and hydraulic brake fluids [6].

Ethylene glycol ether may cause adverse hematological effects through inhalation, dermal absorption, and ingestion. It was suggested that skin absorption of $\mathrm{BE}$ is a predominant factor in occupational exposure [7]. Such ether is oxidized by NAD-dependent dehydrogenases in the liver, testicles, and skin $[8,9]$ to corresponding alkoxyacetic acids (AAs), which have been identified as primary urinary metabolites in humans and animals. Alkoxyacetic acids are responsible for toxic effects of EGEs [10]. These metabolites exert inhibitory effect on $\mathrm{Na}^{+}-, \mathrm{K}^{+}$- and $\mathrm{Ca}^{2+}$-ATPase in erythrocyte membrane in vitro [11].

Data on human exposure to EGEs indicates that ME in occupational conditions lead to leucopenia, pancytopenia, bone marrow depression, and decline in the number of red blood cells (RBC), and hemoglobin concentration [12]. In male impregnation workers chronically exposed to ME, the HGB, packed cell volume (PCV), and RBC were significantly lower in com- parison with the control group (laminate workers) [13]. The frequency of anemia in the group exposed to ME was significantly higher as compared to the corresponding control group. While, RBC was significantly negatively associated with air concentrations of ME, HGB, $\mathrm{PCV}$, and RBC were negatively correlated with urinary levels of methoxyacetic acid (MAA), a metabolite of ME. Similarly, in another survey of male workers chronically exposed to ME, similar hematological disorders in peripheral blood were observed [14].

In shipyard painters exposed to mixed solvents containing 2-ethoxyethanol acetate it was observed that this chemical might be toxic to the bone marrow [15].

In the workers exposed to a low level of $\mathrm{BE}$, a statistically significant decrease in PCV value and an increase in mean cell hemoglobin concentration (MCHC) value were seen [16].

Ethylene glycol ether is often used as mixtures in industrial or domestic solvent compositions [17]. To our knowledge, there are no studies describing the hematological effects of repeated exposure to any mixtures of these chemicals in experimental animals. The objective of this study has been to evaluate the effects of ME and $\mathrm{EE}$ on hematological changes induced by $\mathrm{BE}$ in rats.

\section{MATERIAL AND METHODS}

\section{Chemicals}

The substances: ME, EE, and BE were purchased from Sigma-Aldrich Ltd, Poland. Other chemicals were obtained from POCH (Poland). Methoxyethanol, EE, and $\mathrm{BE}$ solutions and their mixtures were made up in saline, immediately before dosing.

\section{Animals}

Adult male Wistar rats (12 weeks old, with an initial body weight about $290 \mathrm{~g}$ ) were purchased from the Jagiellonian University, Pharmacy Breeding Laboratory (Kraków, Poland). The animals were kept in clean polypropylene cages under standard laboratory conditions (temperature at $22 \pm 2^{\circ} \mathrm{C}$, relative humidity of $50 \pm 10 \%$ and a $12 / 12 \mathrm{~h}$ light/dark cycle, the light on at 8:00), with food (Murigram, Motycz, Poland) and water available ad libitum. All the treatments were started after at least 1 week of acclimatization to laboratory conditions.

All experiments were carried out according to the National Institutes of Health Guide for the Care and Use of Laboratory Animals, and were approved by 
the Local Ethics Committee, Kraków, Poland (the certificate No. 33/2008).

\section{Animal treatment}

The rats were randomly assigned to 11 groups of 5 animals each. The rats (6 groups) were treated with $\mathrm{BE}, \mathrm{ME}$, and $\mathrm{EE}$ alone in doses of 0.75 and $1.25 \mathrm{mM} / \mathrm{kg} / \mathrm{day}$ by subcutaneous injections at a fixed volume of $2 \mathrm{ml} / \mathrm{kg}$ of body weight (b.w.), regardless of a dose, once daily, 5 days per week, for 4 weeks. Other 4 groups of rats were exposed to 2-component mixtures of the examined compounds, i.e., $\mathrm{BE}$ and $\mathrm{ME}$ or $\mathrm{BE}$ and $\mathrm{EE}$, in the same manner and in the same doses with the molar ratio 1:1. Control rats (1 group) were given the equivalent volume of saline. The applied doses and route of administration were chosen based on the previous work output [18].

Blood samples from the tail vein of rats were collected for hematological analyses directly before the experiment, during exposure and after its termination, i.e., on the day $0,4,11,18$, and 29.

\section{Hematological analyses}

Data on the hematological analyses has been described elsewhere [18]. Hematological analyses were systematically checked. To this end a standard human blood CBC-3D Hematology Control (R\&D System Inc., Minneapolis, MN, USA) was used. A dayto-day precision of $\mathrm{RBC}, \mathrm{PCV}$, and mean corpuscular volume (MCV) measurements $(\mathrm{N}=25)$ in blood stood at $4.4 \%, 4.8 \%$, and $4.6 \%$, respectively.

\section{Urine examination}

Rats treated with $\mathrm{BE}$ in a dose of $1.25 \mathrm{mM} / \mathrm{kg} /$ day or exposed to $\mathrm{BE}$ and $\mathrm{ME}$ or $\mathrm{BE}$ and $\mathrm{EE}$ mixtures in the same doses were placed in individual glass metabolic cages for urine collection. Urine was collected every day for the first 3 days of exposure. Hemoglobin concentration was determined by means of Drabkin's method and creatinine level - by means of Jaffe's reaction. The HGB concentration in urine was calculated for $1 \mathrm{~g}$ creatinine after its determination by Jaffe's reaction.

\section{Statistical analyses}

All data is expressed as mean \pm standard deviation. Data was analyzed by means of a 2-way analysis of variance with repeated measures for 1 factor (time or dose) and evaluation of simple effects. The analysis was performed with the SPSS 14.0 statistical packet (SPSS Inc., Chicago, IL, USA). Results were considered statistically significant when $\mathrm{p} \leq 0.05$.

\section{RESULTS}

\section{Hematological effects}

2-Butoxyethanol alone, administered in the lower dose of $0.75 \mathrm{mM} / \mathrm{kg} /$ day caused a significant decrease in RBC on each test day, PCV - only on the day 4, and HGB - on the days 4, 11, and 29 of the experiment. Moreover, an increase in both MCV on each test day, and reticulocyte (RET) on the days 4 , and 11 was observed (Figure 1).

2-Methoxyethanol alone in the same dose as $\mathrm{BE}$ $(0.75 \mathrm{mM} / \mathrm{kg} / \mathrm{day})$ led to only a weakly pronounced but statistically significant decrease in RBC on the day 18 of exposure. In the rats co-exposed to $\mathrm{BE}$ and $\mathrm{ME}$ in the lower doses $(0.75 \mathrm{mM}+0.75 \mathrm{mM})$, significantly less pronounced hematological changes vs. BE alone group were seen on the days 4 or 4 and 11, mainly in PCV, HGB, and RBC, respectively. In these rats significantly less pronounced changes in MCV in comparison with animals exposed to $\mathrm{BE}$ alone on each test day were observed. In a later period, i.e., mainly on the days 18 and 29 of exposure, the hematological alterations (RBC, PCV, HGB, and RET) in rats simultaneously treated with $\mathrm{BE}$ and $\mathrm{ME}$ were similar or more pronounced than after $\mathrm{BE}$ alone treatment (Figure 1).

2-Butoxyethanol administration in a dose of $1.2 \mathrm{mM} / \mathrm{kg} /$ day resulted in a decrease in $\mathrm{RBC}$ and also in an increase in both MCV, and RET on each test day. The decline in PCV on the days 4 and 18, and HGB on the days 4,18 , and 29 was also observed. In addition, BE in the administered dose caused secondary hemoglobinuria on the day 1 of exposure. Hemoglobin concentrations in urine of treated and control rats were $345 \pm 6.1 \mathrm{mg} / \mathrm{g}$ of creatinine and $43 \pm 7.9 \mathrm{mg} / \mathrm{g}$ of creatinine, respectively.

2-Methoxyethanol only in the higher dose of $1.25 \mathrm{mM} / \mathrm{kg} /$ day caused a decrease in $\mathrm{RBC}$ on the day 18, and also PCV and HGB on the days 18 and 29 (Figure 2).

In the rats co-exposed to $\mathrm{BE}$ and $\mathrm{ME}$ in the higher doses $(1.25 \mathrm{mM}+1.25 \mathrm{mM})$, significantly less pronounced hematological changes in PCV, HGB, and RET, in comparison to the BE alone group on the day 4 of exposure were observed. In a later period, i.e., on the days 11,18 , and 29 of exposure, the hematological alterations (RBC, PCV, HGB, MCV, and RET) were similar or greater than in the rats treated with $\mathrm{BE}$ alone. At the end of the experiment, i.e., on the day 29, the greatest changes in RBC, PCV, and HGB were observed (Figure 2). 
a)

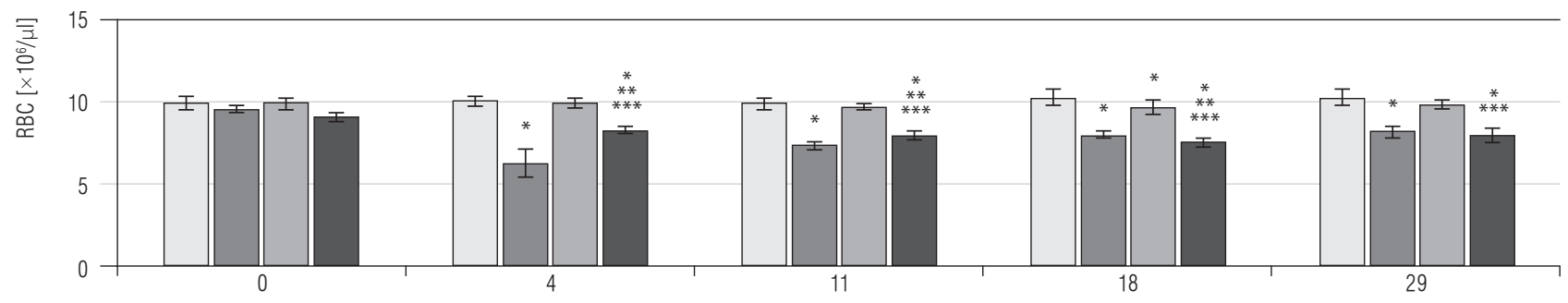

$\square$ control rats $\square$ BE $\square$ ME $\square$ BE+ME

Day / Dzień

b)

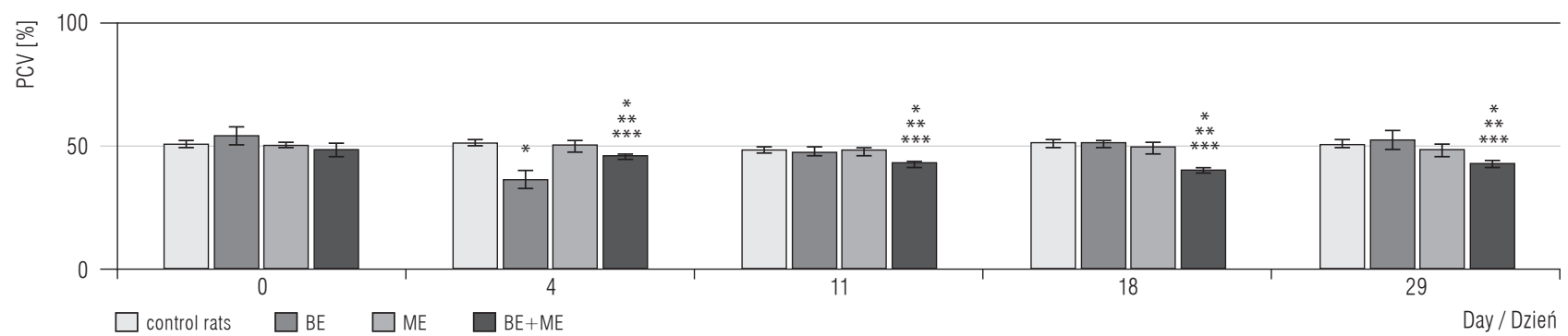

c)

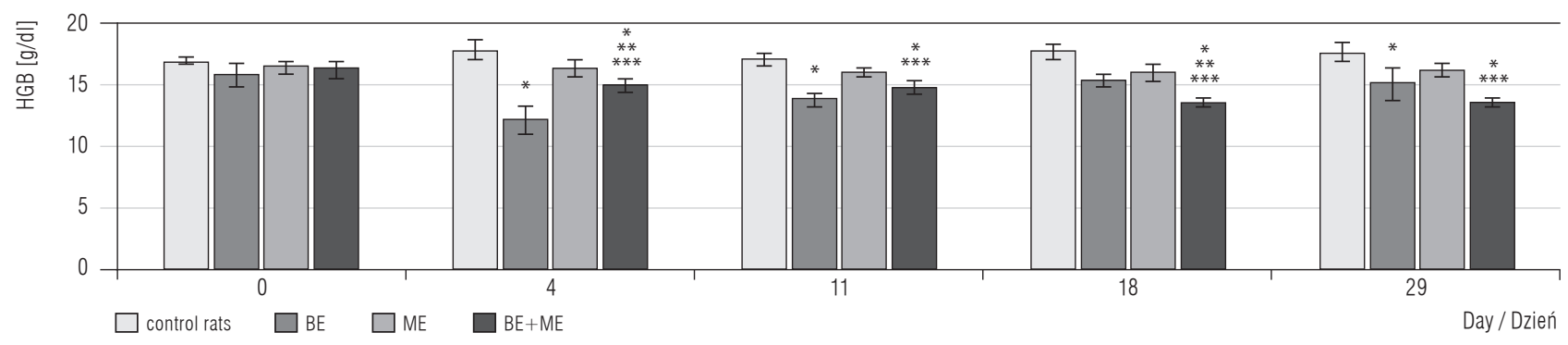

d)

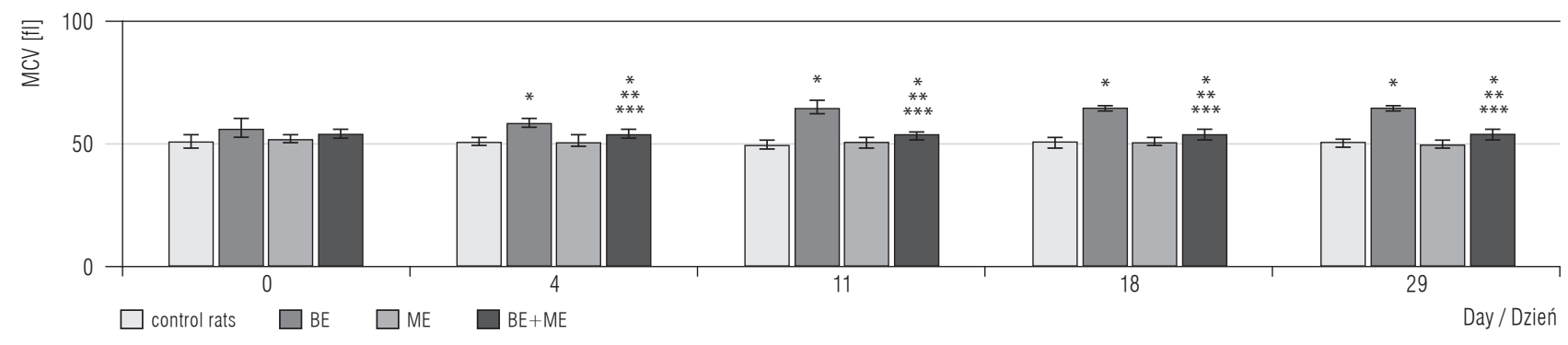

e)

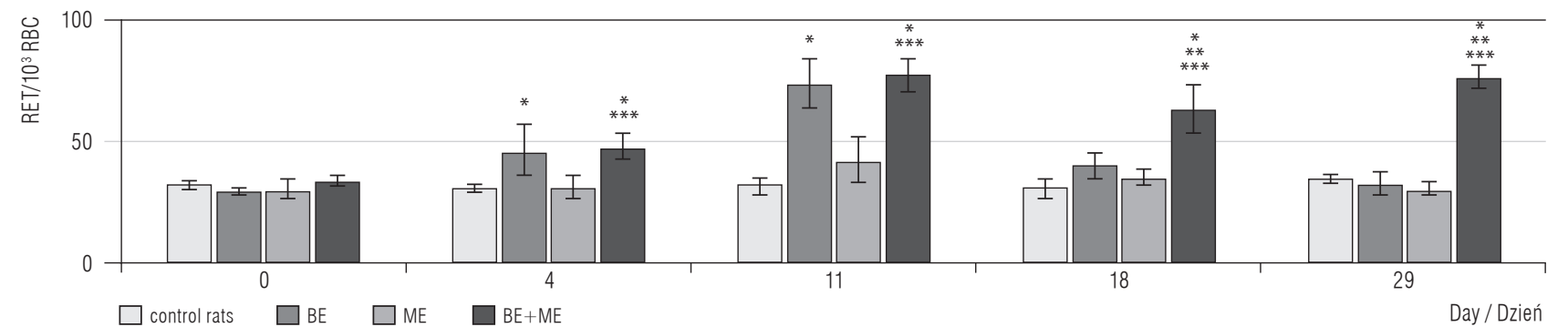

RBC - red blood cells / czerwone krwinki, PCV - packed cell volume / hematokryt, HGB - hemoglobin / hemoglobina, MCV - mean corpuscular volume of red blood cell / średnia objętość krwinki czerwonej, RET - reticulocytes / retikulocyty. $\mathrm{p} \leq 0.05$ significantly different / istotnie różny:

* from control rats / w stosunku do grupy kontrolnej,

** from rats treated with BE alone / w stosunku do grupy narażonej tylko na BE,

${ }_{* * *}^{*}$ from rats treated with ME alone / w stosunku do grupy narażonej tylko na ME.

The values are the means \pm standard deviation of 5 rats / Wartości przedstawiono jako średnią arytmetyczną \pm odchylenie standardowe dla 5 szczurów.

Fig. 1. The effects of combined exposure to 2-butoxyethanol (BE) and 2-methoxyethanol (ME) in the doses of $0.75 \mathrm{mM} / \mathrm{kg}$ b.w. on: a) $\mathrm{RBC}$, b) PCV, c) HGB, d) MCV, e) RET values in peripheral blood in male rats

Ryc. 1. Wpływ łącznego narażenia na 2-butoksyetanol (BE) i 2-metoksyetanol (ME) w dawkach 0,75 mM/kg m.c. na: a) RBC, b) PCV, c) HGB, d) MCV, e) RET we krwi obwodowej samców szczurów 

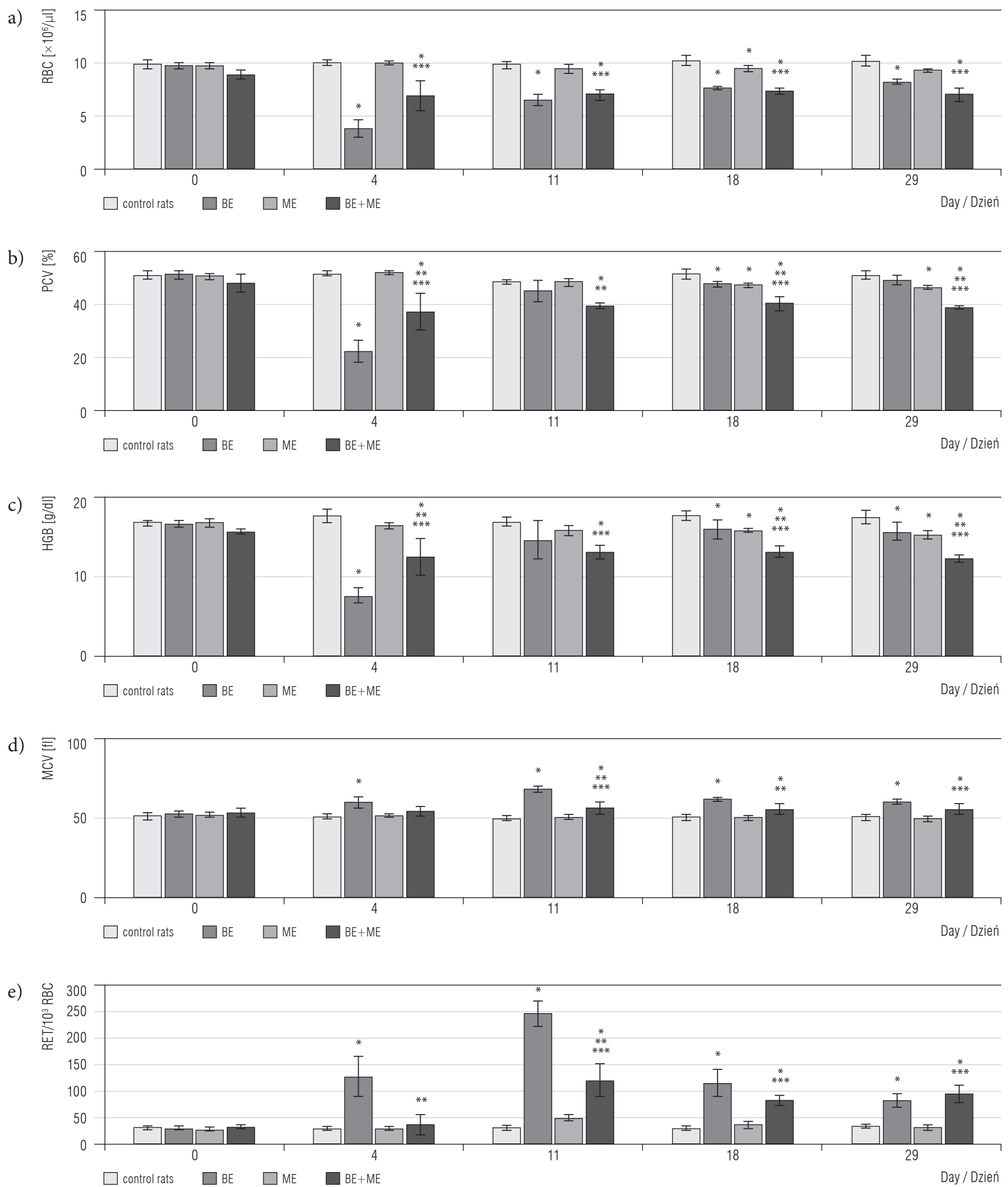

Abbreviations as in Figure 1/ Objaśnienia jak na rycinie 1.

Fig. 2. The effects of combined exposure to BE and ME in the doses of $1.25 \mathrm{mM} / \mathrm{kg}$ b.w. on: a) RBC, b) PCV, c) HGB, d) MCV, e) RET values in peripheral blood in male rats

Ryc. 2. Wpływ łącznego narażenia na BE i ME w dawkach 1,25 mM/kg m.c. na: a) RBC, b) PCV, c) HGB, d) MCV, e) RET we krwi obwodowej samców szczurów 
a)

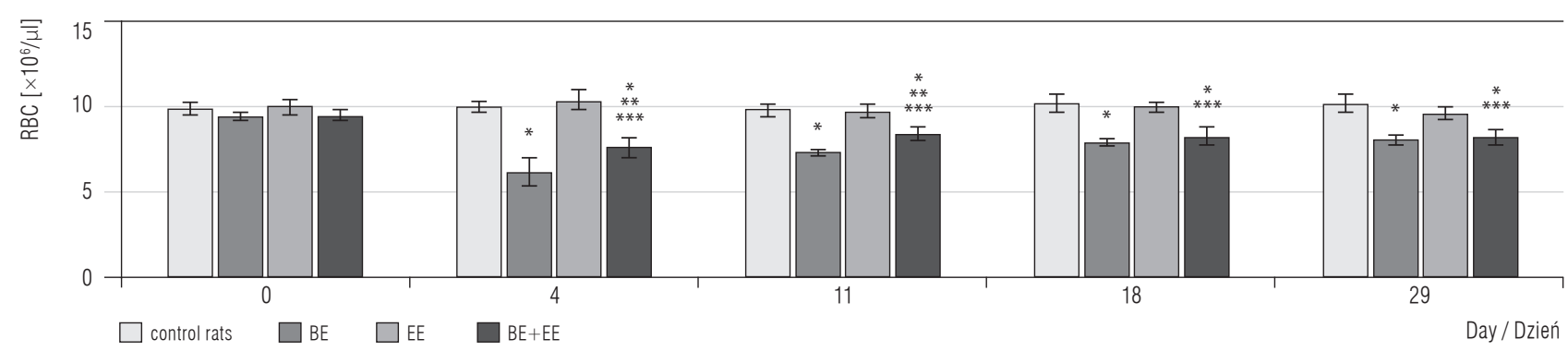

b)

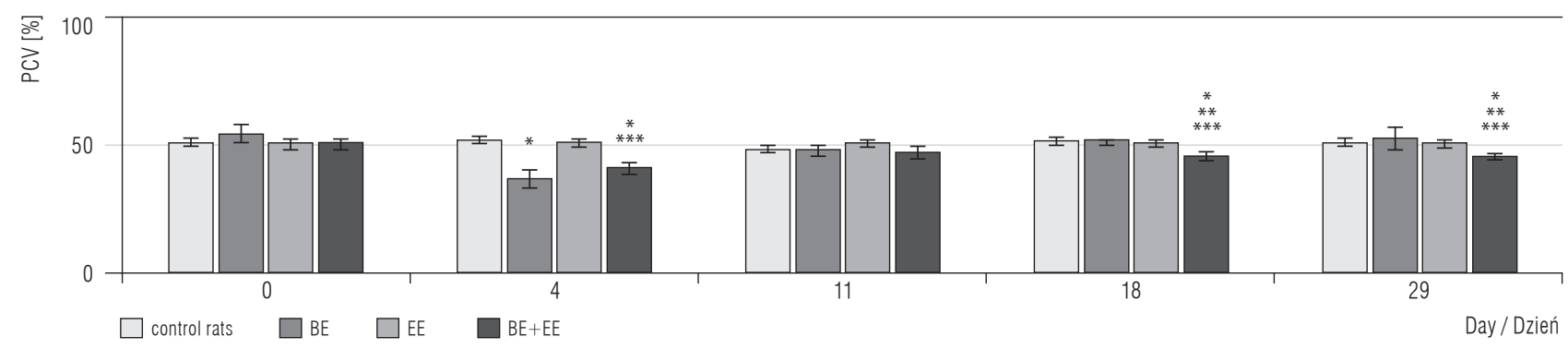

c)

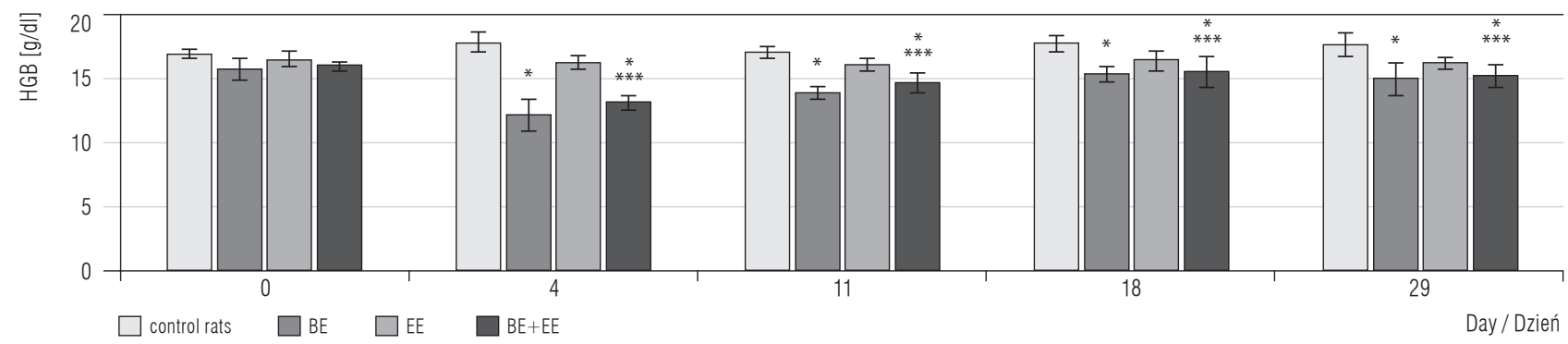

d)



e)
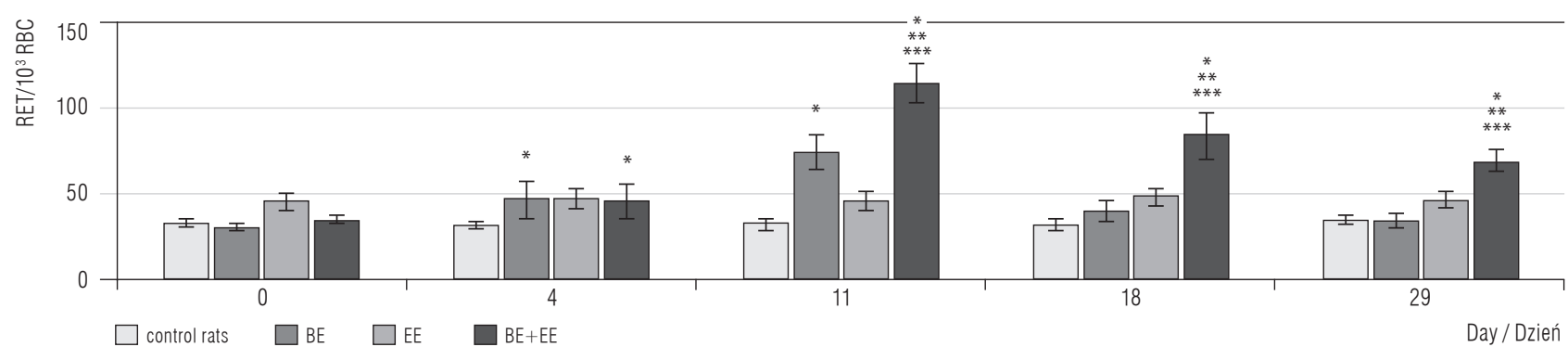

*** from rats treated with EE alone / w stosunku do grupy narażonej tylko na EE.

Other abbreviations as in Figure 1 / Inne objaśnienia jak na rycinie 1.

Fig. 3. The effects of combined exposure to BE and 2-ethoxyethanol (EE) in the doses of $0.75 \mathrm{mM} / \mathrm{kg}$ b.w. on: a) RBC, b) PCV, c) HGB, d) MCV, e) RET values in peripheral blood in male rats

Ryc. 3. Wpływ łącznego narażenia na BE i 2-etoksyetanol (EE) w dawkach 0,75 mM/kg m.c. na: a) RBC, b) PCV, c) HGB,

d) MCV, e) RET we krwi obwodowej samców szczurów 
a)

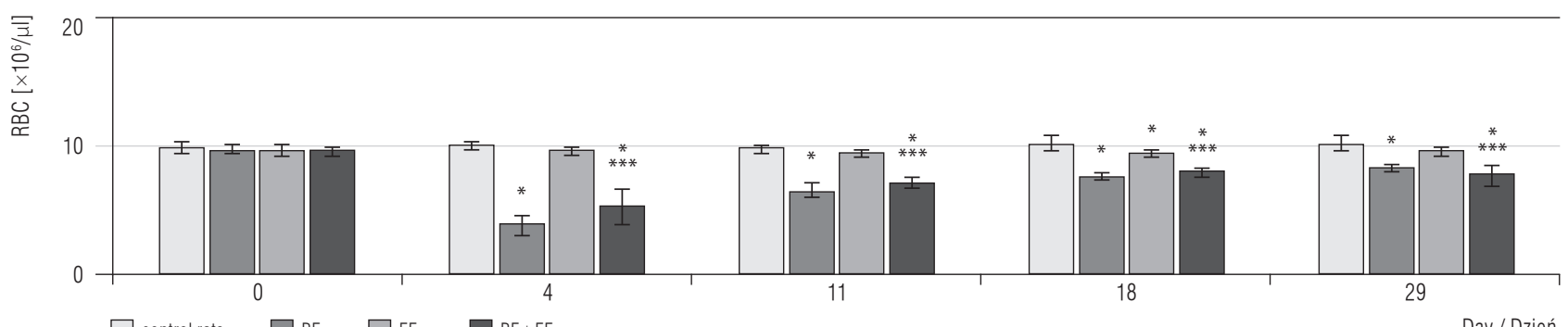

b)

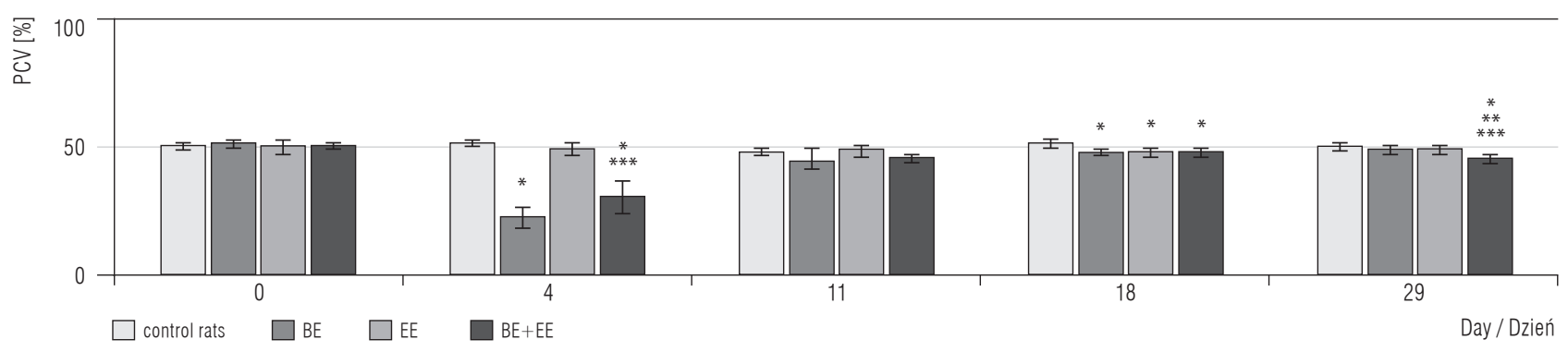

c)

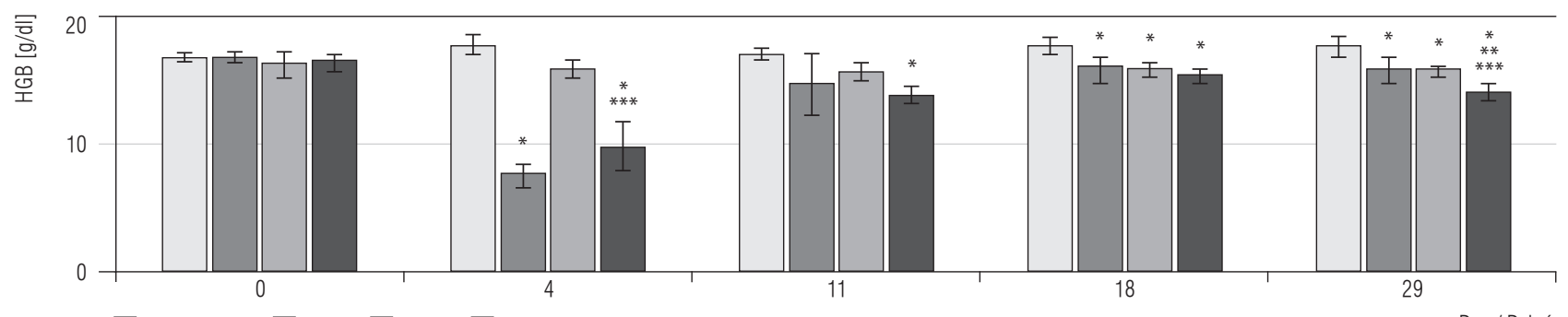

$\square$ control rats $\square$ BE $\square$ EE $\square$ BE+EE

Day / Dzień

d)

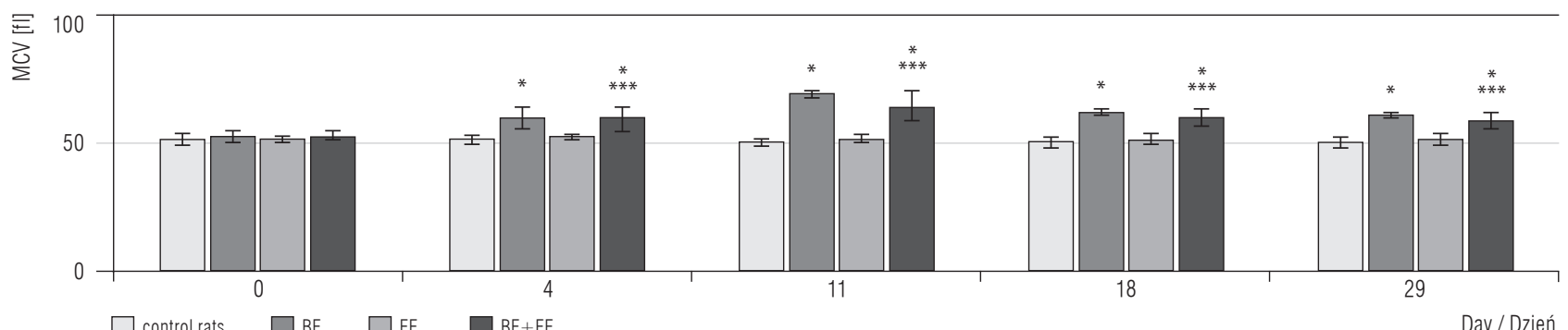

e)

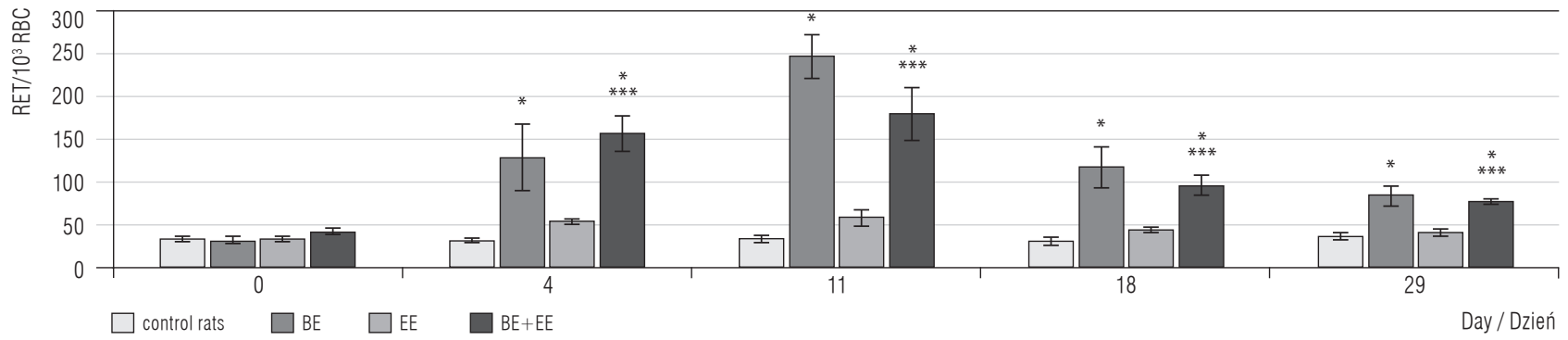

Abbreviations as in Figure 1 and 3 / Objaśnienia jak na rycinie 1 i 3.

Fig. 4. The effects of combined exposure to BE and EE in the doses of $1.25 \mathrm{mM} / \mathrm{kg}$ b.w. on: a) RBC, b) PCV, c) HGB, d) MCV, e) RET values in peripheral blood in male rats

Ryc. 4. Wpływ łącznego narażenia na BE i EE w dawkach 1,25 mM/kg m.c. na: a) RBC, b) PCV, c) HGB, d) MCV,

e) RET we krwi obwodowej samców szczurów 
In contrast, EE produced less pronounced effects on circulating $\mathrm{RBC}$ than $\mathrm{BE}$ or $\mathrm{ME}$ alone. The lower dose of $\mathrm{EE}(0.75 \mathrm{mM} / \mathrm{kg} /$ day $)$ did not induce hematological alterations (Figure 3). Only the higher dose of this compound $(1.25 \mathrm{mM} / \mathrm{kg})$ resulted in a decrease in RBC and PCV on day 18, and HGB on the days 18 and 29 (Figure 4).

In the rats concurrently treated with $\mathrm{BE}$ and $\mathrm{EE}$ in the lower doses $(0.75 \mathrm{mM} / \mathrm{kg}+0.75 \mathrm{mM} / \mathrm{kg})$, a significantly less pronounced decrease in $\mathrm{RBC}$ than in $\mathrm{BE}$ alone group was found on the days 4 and 11. In a later period (on the days 18, and 29) the same values of $\mathrm{RBC}$ and HGB, and a greater decrease in PCV in comparison to BE group were observed. While the increase in MCV was significantly lower than in the rats treated with $\mathrm{BE}$ alone on each test day, RET were distinctly elevated on the days 11, 18 and 29 (Figure 3). In the rats co-exposed to the higher doses of $\mathrm{BE}$ and $\mathrm{EE}$ $(1.25 \mathrm{mM} / \mathrm{kg}+1.25 \mathrm{mM} / \mathrm{kg})$ the hematological changes were similar (RBC, MCV, and RET on the days from 4 to 29) or more pronounced (PCV and HGB on the day 29) than in the rats treated with $B E(1.25 \mathrm{mM} / \mathrm{kg})$ alone (Figure 4).

The rats concurrently exposed to $\mathrm{BE}$ and $\mathrm{ME}$ or $\mathrm{BE}$ and EE did not demonstrate hemoglobinuria on the 1st day of exposure. Hemoglobin concentrations in urine of these rats were similar to the control group $(66 \pm 23.6$ and $62 \pm 13.4 \mathrm{mg} / \mathrm{g}$ of creatinine, respectively).

\section{Leukocyte alterations}

In the rats treated with $\mathrm{BE}$ alone in a dose of $0.75 \mathrm{mM} / \mathrm{kg} / \mathrm{day}$, white blood cells (WBC) did not change, while lymphocyte (LYM) count was reduced on the days 11, 18, and 29 of the experiment. There were no significant $\mathrm{WBC}$ and LYM alterations in rats exposed to $\mathrm{ME}$ alone in a dose of $0.75 \mathrm{mM} / \mathrm{kg} /$ day. The LYM count in the rats co-exposed to the lower doses of $\mathrm{BE}$ and $\mathrm{ME}(0.75 \mathrm{mM}+0.75 \mathrm{mM})$ was significantly higher in comparison to the group treated with $\mathrm{BE}$ alone on the days 11, 18, and 29. These values were similar as in the control group on each test day, except for the day 29 of the experiment (Figure 5).

2-Butoxyethanol administration in a dose of $1.25 \mathrm{mM} / \mathrm{kg} /$ day resulted in a decrease in WBC on the day 4 and LYM on the days 18, and 29 of the experiment. In rats treated with $\mathrm{ME}$ alone in a dose of $1.25 \mathrm{mM} / \mathrm{kg} / \mathrm{day}, \mathrm{WBC}$ and LYM counts were decreased on the day 4. No WBC and LYM alterations in rats co-exposed to $\mathrm{BE}$ and $\mathrm{ME}$ in the higher doses $(1.25 \mathrm{mM}+1.25 \mathrm{mM})$ on any test day were seen, except for the day 29 of exposure when LYM count was lower than in the control group (Figure 6). a)

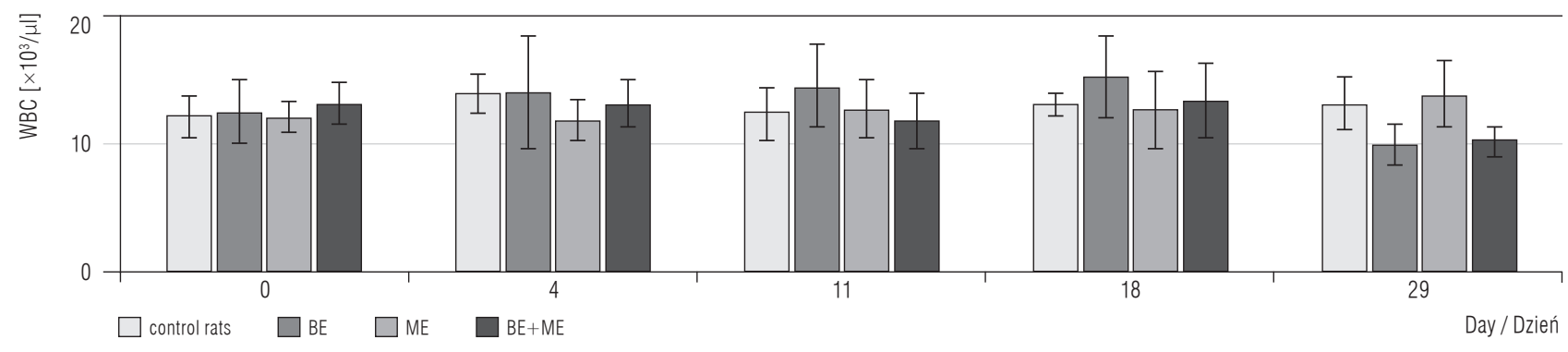

b)

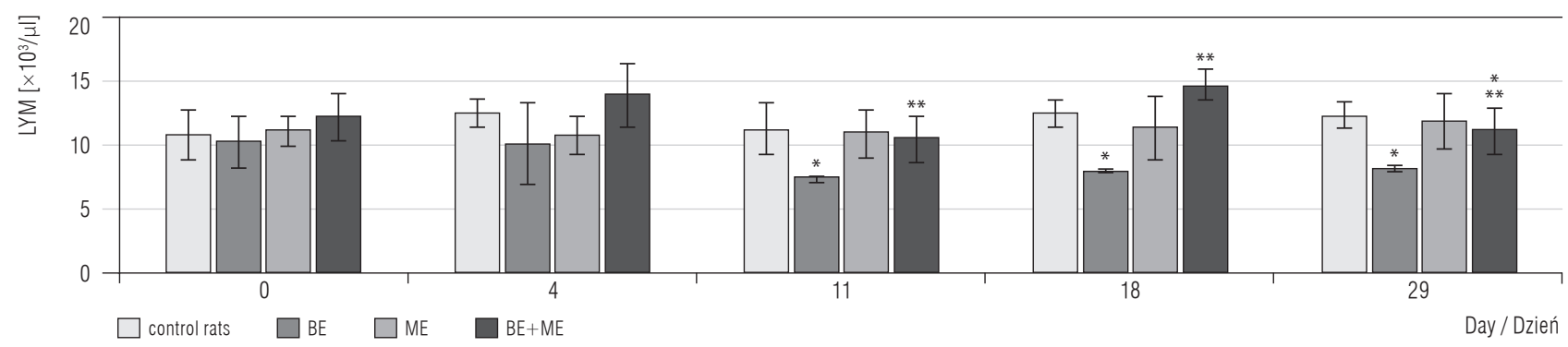

WBC - white blood cells / białe krwinki, LYM - lymphocytes / limfocyty.

Other abbreviations as in Figure 1 / Inne objaśnienia jak na rycinie 1.

Fig. 5. The effects of combined exposure to BE and ME in the doses of $0.75 \mathrm{mM} / \mathrm{kg}$ b.w. on: a) WBC, b) LYM values in peripheral blood in male rats

Ryc. 5. Wpływ łącznego narażenia na BE i ME w dawkach 0,75 mM/kg m.c. na liczbę: a) WBC, b) LYM we krwi obwodowej samców szczurów 
No significant changes in WBC and LYM count were observed in the rats treated with $\mathrm{EE}$ in a dose of $0.75 \mathrm{mM} / \mathrm{kg} /$ day. Co-exposure to the lower doses of $\mathrm{BE}$ and $\mathrm{EE}(0.75 \mathrm{mM}+0.75 \mathrm{mM})$ led to the increase in LYM on the day 18 in comparison to the rats exposed to BE alone. On the day 29 LYM count was similar as in the group treated with $\mathrm{BE}$ alone but significantly lower than in the control group (Figure 7).

a)



b)

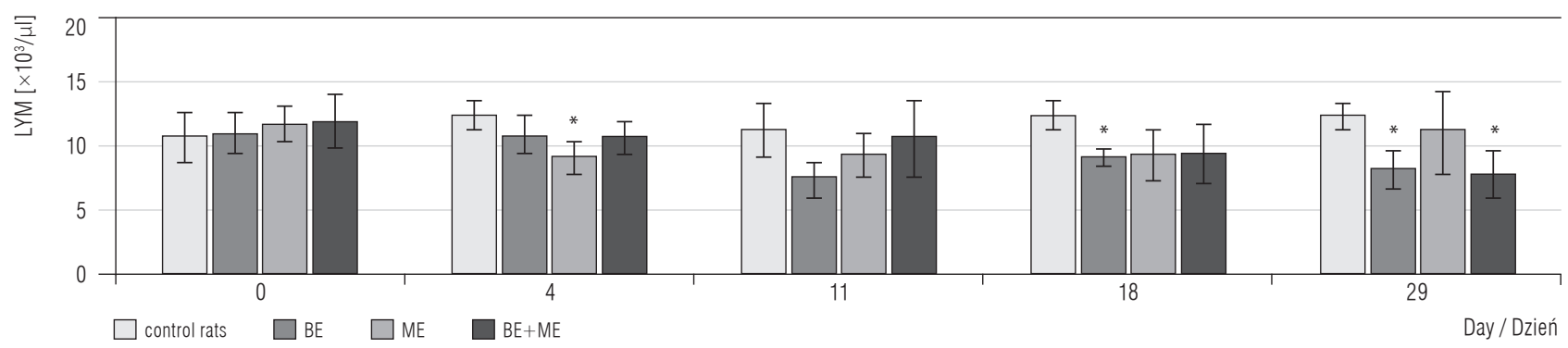

Abbreviations as in Figure 1 and 5 / Objaśnienia jak na rycinie 1 i 5.

Fig. 6. The effects of combined exposure to BE and ME in the doses of $1.25 \mathrm{mM} / \mathrm{kg}$ b.w. on: a) WBC, b) LYM values in peripheral blood in male rats

Ryc. 6. Wpływ łącznego narażenia na BE i ME w dawkach 1,25 mM/kg m.c. na liczbę: a) WBC, b) LYM we krwi obwodowej samców szczurów

a)

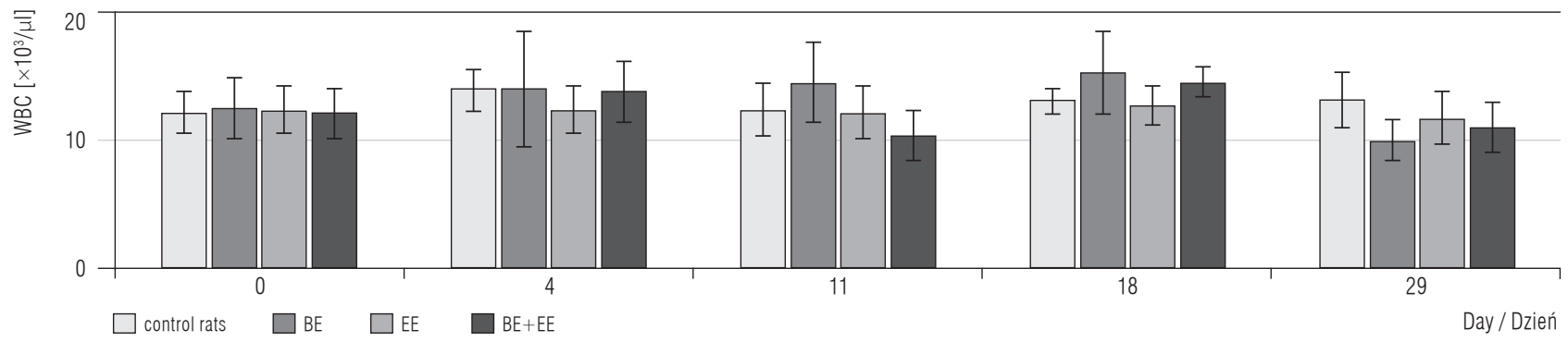

b)

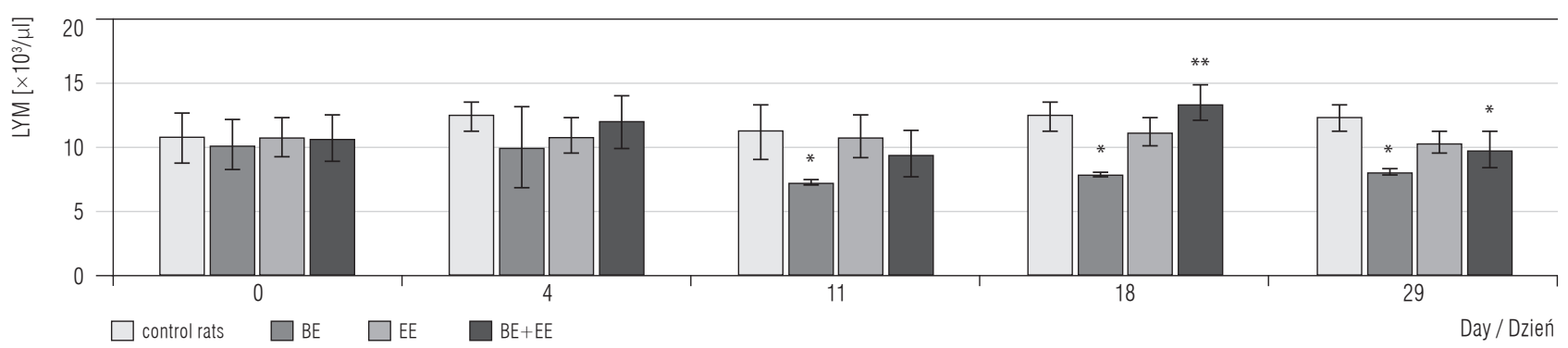

Abbreviations as in Figure 1, 3 and 5 / Objaśnienia jak na rycinie 1, 3 i 5.

Fig. 7. The effects of combined exposure to BE and EE in the doses of $0.75 \mathrm{mM} / \mathrm{kg}$ b.w. on: a) WBC, b) LYM values in peripheral blood in male rats

Ryc. 7. Wpływ łącznego narażenia na BE i EE w dawkach 0,75 mM/kg m.c. na liczbę: a) WBC, b) LYM we krwi obwodowej samców szczurów 
a)

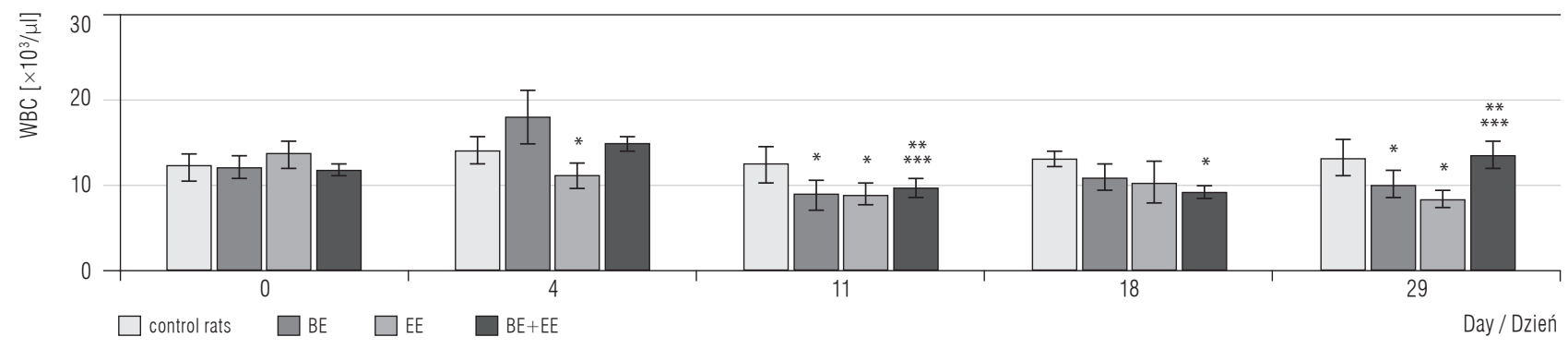

b)



Abbreviations as in Figure 1, 3 and 5 / Skróty i objaśnienia jak na rycinie 1, 3 i 5.

Fig. 8. The effects of combined exposure to BE and EE in the doses of $1.25 \mathrm{mM} / \mathrm{kg}$ b.w. on: a) WBC, b) LYM values in peripheral blood in male rats

Ryc. 8. Wpływ łącznego narażenia na BE i EE w dawkach 1,25 mM/kg m.c. na liczbę: a) WBC, b) LYM we krwi obwodowej samców szczurów

The higher dose of EE $(1.25 \mathrm{mM} / \mathrm{kg} /$ day $)$ diminished WBC on the days 4,11 , and 29 and also reduced LYM on the days 11, 18, and 29 in comparison to the control group. In the rats concurrently treated with $\mathrm{BE}$ and $\mathrm{EE}(1.25 \mathrm{mM}+1.25 \mathrm{mM}) \mathrm{WBC}$ count was similar as in the control group and significantly higher than in the rats exposed to $\mathrm{BE}(1.25 \mathrm{mM} / \mathrm{kg} /$ day $)$ alone on the days 11 and 29. On the day 18 this parameter did not differ from BE or EE groups but was significantly lower than in the control group. On the day 29, the LYM count in these rats was higher in comparison to the rats treated with $\mathrm{BE}$ or EE alone and did not differ vs. control rats. On the days 11 and 18 LYM count was lower than in the control group but did not differ from groups exposed to BE or EE alone (Figure 8).

\section{DISCUSSION}

So far, hematological toxicity of EGEs in humans and animals has been well documented [12-14,16,19]. In this study a short-chain EGEs (ME and EE) in a relatively low dose $(1.25 \mathrm{mM} / \mathrm{kg} /$ day $)$ exerted weak hematotoxic effects evidenced by reduction in $\mathrm{RBC}, \mathrm{PCV}$, HGB, WBC and LYM in peripheral blood. Under the same condition of exposure to both kinds of ether given separately, in the higher doses $(2.5 \mathrm{mM} / \mathrm{kg} / \mathrm{day}$ and $5.0 \mathrm{mM} / \mathrm{kg} /$ day), additionally an increase in $\mathrm{MCV}$ and RET was observed [19]. The results obtained in this study indicate that the hematological alterations expressed mainly in terms of the decrease in RBC, PCV, and HGB seen exclusively at the end of exposure (on the days 11, 18 or 29) were rather persistent at low level. In principle, no hematological changes in the low level dose $(0.75 \mathrm{mM} / \mathrm{kg} /$ day $)$ of both examined kinds of ether were found. Similarly, as in the previous study [19], neither of these kinds of ether did not induce hemolysis.

Contrary to the $\mathrm{ME}$ and $\mathrm{EE}$, the potent hematotoxic effects in experimental animals were exerted by BE. This ether alone in relatively low doses $(0.75 \mathrm{mM} / \mathrm{kg}$ /day and $1.25 \mathrm{mM} / \mathrm{kg} /$ day), corresponding to below $0.16-$ $0.26 \mathrm{LD}_{50}$ p.o. (median lethal dose per os) value [20], caused considerable hematological changes, including the decrease in RBC, PCV, HGB, WBC, and LYM as well as the increase in MCV, and RET. These changes, except for WBC and LYM, were most pronounced at the beginning of exposure (on the day 4), and then in general were regressed despite of exposure duration, except for the increase in MCV and RET which were persistent during all the exposure period. The lymphocytes count was significantly reduced mainly on the days 18 and 29 of the experiment. Moreover, BE led to apparent hemolysis expressed in the hemoglobinuria only on the 1st day of exposure to a higher dose of this ether $(1.25 \mathrm{mM} / \mathrm{kg} /$ day $)$. 
It was suggested that hematological disturbances induced by $\mathrm{BE}$ in this experiment and the previous study [19] are probably the result of the selective hemolysis of the aged erythrocytes. There are many evidences that the aging process of RBC leads to several biochemical alterations and to the loss cell deformability and the increased MCV value and osmotic fragility [21,22]. It seems that selective hemolysis of older erythrocytes together with the process of active blood regeneration may lead to tolerance development to the hemolytic action of BE $[19,23,24]$. On the other hand, the lack of tolerance to ME- and EE-induced hemolysis in rats treated with these kinds of ether was observed.

The main aim of this study has been the evaluation of the effects of ME and EE on the hematological changes induced by $\mathrm{BE}$ in rats. The obtained results show that short-chain ether could modify the hematological impact of BE. This modification, especially by ME, was characterized by 2 -step hematological alterations in a different manner than those induced by $\mathrm{BE}$ alone. At the beginning of the exposure (mainly on the day 4 ), the attenuation of the hematotoxic effects of $\mathrm{BE}$ expressed in terms of higher values of RBC, PCV, and HGB, and lower values of MCV and RET as well as the lack of hemoglobinuria was seen. On the other hand, at the end of exposure (from the days 11 to 29) these alterations were more pronounced, except for a decrease in MCV for all the exposure period and RET on the days 18 and 29 in the rats co-exposed to $\mathrm{BE}$ and $\mathrm{ME}$ in the higher doses $(1.25 \mathrm{mM} / \mathrm{kg} / \mathrm{day}+1.25 \mathrm{mM} / \mathrm{kg} /$ day $)$. The effects of EE on hematological changes induced by $\mathrm{BE}$ were less pronounced than ME.

The obtained data demonstrates that in rats concurrently treated with $\mathrm{BE}$ and $\mathrm{ME}$ or $\mathrm{BE}$ and $\mathrm{EE}$ the hematological changes have the opposite direction of the course than those in animals exposed to BE alone. Thus, the short-chain ether disturbs the tolerance development to the hemolytic action of BE.

In contrast with the above described changes, in the leukocyte system both kinds of ether (ME in the dose of $0.75 \mathrm{mM} / \mathrm{kg} /$ day and EE in doses of $0.75 \mathrm{mM} / \mathrm{kg} /$ day and $1.25 \mathrm{mM} / \mathrm{kg} /$ day) co-administered with BE resulted in an increase of the number of lymphocytes at the end of exposure. These results are insufficient for the suggestion that co-exposure to $\mathrm{BE}$ and $\mathrm{ME}$ or $\mathrm{BE}$ and $\mathrm{EE}$ may counteract lymphocytopenia and immunosuppression induced by each ether alone, especially at higher exposure level [19].

In this study, the action of a single compound and 2-component mixtures: the 1st one with lipophilic properties (BE) and the 2nd hydrophilic one (ME and EE), on the hematological parameters, was examined. In fact, industry workers are exposed mainly to mixtures of EGEs [17]. Also, in household preparations these kinds of ether occur as mixtures.

Few studies, in which the mixtures of EGEs or composition of these kinds of ether with other chemicals were administered, indicate that examined compounds could modify each other's toxic effects. For example, ME attenuated hematotoxic action of isopropoxyethanol (IPE) in rats at the beginning of the exposure increased its harmful effects at the end of the treatment [18]. Aliphatic alcohols, i.e., ethanol, n-propanol, and n-butanol, almost completely inhibited the hemolytic effect of $\mathrm{BE}$ in rats, and significantly reduced the urinary excretion of butoxyacetic acid (BAA), a metabolite of BE.

In contrast, co-administration of these alcohols with ME did not change the $24 \mathrm{~h}$ urinary excretion of MAA. It was suggested that competitive inhibition of alcohol dehydrogenase (ADH) by alcohols results in the diversion of BE metabolism but not ME [25]. In the other study performed on the rats, the intake of ethanol along with short-term repeated exposure to $\mathrm{ME}, \mathrm{EE}(2.5 \mathrm{mM} / \mathrm{kg} / \mathrm{day}$ and $5.0 \mathrm{mM} / \mathrm{kg} /$ day $)$ or $\mathrm{BE}$ $(0.75 \mathrm{mM} / \mathrm{kg} /$ day and $1.25 \mathrm{mM} / \mathrm{kg} /$ day $)$ led to markedly ameliorated hematological parameters, as compared to those which were altered by these ethers alone [26].

The data cited above indicates that the interactions between EGEs exclusively or these kinds of ether and other compounds may be related to the metabolism of these substances. An increasing body of evidence shows that metabolic activation of EGEs to the appropriate AAs is prerequisite for hematotoxic and other harmful effects induced by these chemicals [27].

The basal layer of the epidermis contains enzymes that have the capacity to metabolize EGEs [28]. However, it considers that these kinds of ether are mainly metabolized by the liver.

Common metabolic pathway of EGEs is via alcohol and aldehyde dehydrogenases which lead to the formation of AAs. The other 2 pathways of BE biotransformation involve conjugation with glucuronic acid and sulfate [27]. Whereas MAA is conjugated with glicine to methoxyacetylglicine. No glucuronide of sulphate of ME has been observed in urine [25].

It was found that $\mathrm{BE}$ metabolism to $\mathrm{BAA}$ in vivo is more efficient than biotransformation of ME to MAA and EE to EAA due to the differences in the substrate constant $\left(\mathrm{K}_{\mathrm{m}}\right)$ values which decreased with increasing chain length from ME to BE [8]. Thus, at low and 
similar EGEs levels, the metabolism of BE would be more efficient than that of the other 2 kinds of glycol ether. Moreover, the metabolism of BE is saturated at lower concentrations than those of ME and EE. 2-Butoxyacetic acid is not accumulated in the organism whereas both MAA and EAA are accumulated [29].

It seems that the effects of ME and $\mathrm{EE}$ on the hematological alterations induced by $\mathrm{BE}$ are caused by metabolic interactions of examined kinds of ether. 2-Methoxyethanol and EE may inhibit metabolic activation of $\mathrm{BE}$ to $\mathrm{BAA}$ and may increase the formation of glucuronide and sulphate of BE excreted with urine, especially at the beginning of exposure. In the later period, at the end of the exposure there is a possibility of an increase in AAs levels as a result of their accumulation. These suggestions should be confirmed by subsequent studies.

Finally, it should be taken into account that because of the gonadotoxic activity of $\mathrm{ME}$ and $\mathrm{EE}$, their production has been limited whereas the production of $\mathrm{BE}$ which is regarded as safer from a toxicological point of view increased. Currently, above a $1 / 2$ of household preparations contains $\mathrm{BE}$ [6]. In this study, the exposure to both $\mathrm{BE}$ with $\mathrm{ME}$ and $\mathrm{BE}$ with $\mathrm{EE}$ exerted hematotoxic effects in rats, especially at the end of the short-term repeated exposure. The adverse effects of EGEs indicate the need to limit their use, e.g., by larger substitution of propylene glycol ether [30]. Occupational exposure to mixtures of ether and excessive use of the preparations containing EGEs may lead to adverse consequences in the hematological system and other organs.

\section{CONCLUSIONS}

1. The short-term repeated exposure to BE in rats in relatively low doses leads to well-marked hematological changes which are characteristic of hemolytic anemia.

2. The treatment of rats with $\mathrm{ME}$ or $\mathrm{EE}$ alone in the same manner caused relatively less pronounced hematological alterations.

3. 2-Methoxyethanol administered to rats exposed to $\mathrm{BE}$ alone leads to the amelioration in the majority of the hematological parameters and counteracts hemolysis exclusively at the beginning of the exposure.

4. 2-Ethoxyethanol in the same conditions of the experiment exerts qualitatively similar protective effect but quantitatively less pronounced than $\mathrm{ME}$ on the hemolytic action of BE.
5. The hematological changes markedly pronounced and progressively increased with exposure time at the end of the co-exposure to $\mathrm{BE}$ and $\mathrm{ME}$ or $\mathrm{BE}$ and $\mathrm{EE}$ as compared with $\mathrm{BE}$ alone appear to be related with metabolic interactions of these compounds.

\section{REFERENCES}

1. Cronkite EP. Benzene hematotoxicity and leukemogenesis. Blood Cells. 1986;12:129-37, http://dx.doi.org/10. 1289/ehp.8982109.

2. Maltoni C, Ciliberti A, Cotti G, Conti B, Belpoggi F. Benzene, an experimental multipotential carcinogen: Results of the long-term bioassays performed at the Bologne Institute of Oncology. Environ Health Perspect. 1989;82: 109-24, http://dx.doi.org/10.1289/ehp.8982109.

3. Grabowska M, Gumińska M. [The effect of lead and cadmium ions on the activity of ATPases from human erythrocyte membranes]. Folia Med Cracov. 1987;28(1-2): 123-30. Polish.

4. Cullen M, Rado T, Waldron JA, Welch LS. Bone marrow injury in lithographers exposed to glycol ethers and organic solventsused in multicolor offset and ultraviolet curing printing processes. Arch Environ Health. 1984;38:347-54, http://dx.doi.org/10.1080/00039 896.1983.10545819.

5. Ruchaud S, Boiron O, Cicolella A, Lanotte M. Ethylene glycol ethers as hemopoietic toxins - In vitro studies of acute exposure. Leukemia. 1992;6(4):328-34.

6. De Ketttenis P. The historic and current use of glycol ethers: A picture of change. Toxicol Lett. 2005;156:5-11, http://dx.doi.org/10.1016/j.toxlet.2003.12.076.

7. Vincent R, Cicolella A, Subra I, Rieger B, Poirot P, Pierre F. Occupational exposure to 2-butoxyethanol for workers using window cleaning agents. Appl Occup Environ Hyg. 1993;8:580-6, http://dx.doi.org/10.1080/1047 322X.1993.10388162.

8. Aasmoe L, Winberg JO, Aarbakke J. The role of liver alcohol dehydrogenase isoenzymes in the oxidation of glycolethers in male and female rats. Toxicol Appl Pharmacol. 1998;150:86-90, http://dx.doi.org/10.1006/ taap.1998.8410.

9. Lockley DJ, Howes D, Williams FM. Cutaneous metabolism of glycol ethers. Arch Toxicol. 2005;79:160-8, http://dx.doi.org/10.1007/s00204-004-0619-3.

10. Miller RR, Hermann EA, Young JT, Landry TD, Calhoun LL. Ethylene glycol monomethyl ether and propylene glycol monomethyl ether: Metabolism, disposition, and subchronic inhalation toxicity studies. Environ 
Health Perspect. 1984;57:233-9, http://dx.doi.org/10.12 89/ehp.8457233.

11. Szabla J. [Hemolytic effect of ethylene glycol alkyl ethers - The role of ATPases] [dissertation]. Kraków: Jagiellonian University, Phaculty of Pharmacy; 2007. Polish.

12. Larese F, Fiorito A, Zotti RD. The possible haematological effects of glycol monomethyl ether in a frame factory. Br J Ind Med. 1992;49:131-3, http://dx.doi.org/10.1136/ oem.49.2.131.

13. Shih T-S, Hsieh A-T, Liao G-D, Chen Y-H, Liou S-H. Haematological and spermatotoxic effects of ethylene glycol monomethyl ether in copper clad laminate factories. Occup Environ Med. 2000;57:348-52, http://dx.doi. org/10.1136/oem.57.5.348.

14. Shih T-S, Hsieh A-T, Chen Y-H, Liao G-D, Chen C-Y, Chou J-S, et al. Follow up study of haematological effects in workers exposed to 2-methoxyethanol. Occup Environ Med. 2003;60:130-5, http://dx.doi.org/10.1136/ oem.60.2.130.

15. Kim Y, Lee N, Sakai T, Kim KS, Yang JS, Park S, et al. Evaluation of exposure to ethylene glycol monoethyl ether acetates and their possible haematological effects on shipyard painters. Occup Environ Med. 1999;56: 378-82, http://dx.doi.org/10.1136/oem.56.6.378.

16. Haufroid V, Thirion F, Mertens P, Buchet JP, Lison D. Biological monitoring of workers exposed to low levels of 2-butoxyethanol. Int Arch Occup Environ Health. 1997;70:232-6, http://dx.doi.org/10.1007/ s004200050212.

17. Wesołowski W, Gromiec JP. Occupational exposure in Polish paint and lacquer industry. Int J Occup Med Environ Health. 1997;10:79-88.

18. Starek-Świechowicz B, Miranowicz-Dzierżawska K, Szymczak W, Budziszewska B, Starek A. Hematological effects of exposure to mixtures of selected ethylene glycol alkyl ethers in rats. Pharmacol Rep. 2012;64:166-78, http://dx.doi.org/10.1016/S1734-1140(12)70743-0.

19. Starek A, Szymczak W, Zapor L. Hematological effects of four ethylene glycol monoalkyl ethers in short-term repeated exposure in rats. Arch Toxicol. 2008;82:125-36, http://dx.doi.org/10.1007/s00204-007-0236-z.

20. Gingell R, Boatman RJ, Bus JS, Cawley TJ, Knaak JB, Krasavage WJ, et al. Glycol ethers and other selected glycol derivatives. In: Clayton GD, Clayton FE, editors.
Patty's Industrial Hygiene and Toxicology. 4th ed. Vol 2. Part D. New York: John Wiley \& Sons, Inc; 1994. p. 2796.

21. Yargicoğlu P, Gümüslüoriob S, Ağa A, Kipmen Korgun D, Kücükatay V. Effect of sulfur dioxide inhalation on erythrocyte antioxidant status, food intake, and lipid peroxidation during aging. Arch Environ Health. 2001; 56:53-7, http://dx.doi.org/10.1080/00039890109604054.

22. Udden MM. In vitro sub-hemolytic effects of butoxyacetic acid on human and rat erythrocytes. Toxicol Sci. 2002;69:258-64, http://dx.doi.org/10.1093/toxsci/ 69.1.258.

23. Sivarao DV, Mehendale HM. 2-Butoxyethanol autoprotection is due to resilience of newly formed erythrocytes to hemolysis. Arch Toxicol. 1995;69:526-32, http:// dx.doi.org/10.1007/s002040050207.

24. Ghanayem BI, Sanchez IM, Matthews HB. Development of tolerance to 2-butoxyethanol-induced hemolytic anemia and studies to elucidate the under lying mechanisms. Toxicol Appl Pharmacol. 1992;112:198-206, http://dx.doi.org/10.1016/0041-008X(92)90188-X.

25. Morel G, Lambert AM, Rieger B, Subra I. Interactive effect of combined exposure to glycol ethers and alcohols on toxicodynamic and toxicokinetic parameters. Arch Toxicol. 1996;70:519-25, http://dx.doi.org/10.1007/ s002040050309.

26. Starek A, Miranowicz-Dzierżawska K, Starek-Świechowicz B. Interactive effect of combined exposure to ethylene glycol ethers and ethanol on hematological parameters in rats. Health. 2010;2(9):1054-64, http:// dx.doi.org/10.4236/health.2010.29155.

27. Ghanayem BI, Burka LT, Matthews HB. Metabolic basis of ethylene glycol monobutyl ether (2-butoxyethanol) toxicity: Role of alcohol and aldehyde dehydrogenases. J Pharmacol Exp Ther. 1987;242:222-31.

28. Coomes MW, Norling A, Pohl RJ, Muller D, Fouts IR. Foreign compound metabolism by isolated skin cells from the hairless mouse. J Pharmacol Exp Ther. 1983;225:770-7.

29. Aasmoe L, Mathiesen M, Sager G. Elimination of methoxyacetic acid and ethoxyacetic acid in rat. Xenobiotica. 1999;29:417-24, http://dx.doi.org/10.1080/004982 599238597.

30. Spencer PJ. New toxicity data for the propylene glycol ethers - A commitment to public health and safety. Toxicol Lett. 2005;156:181-8, http://dx.doi.org/10.1016/j.toxlet.2003.09.023.

This work is available in Open Access model and licensed under a Creative Commons Attribution-NonCommercial 3.0 Poland License / Ten utwór jest dostępny w modelu open access na licencji Creative Commons Uznanie autorstwa - Użycie niekomercyjne 3.0 Polska - http://creativecommons.org/ licenses/by-nc/3.0/pl/deed.en. 